\title{
PERAN PAMONG BELAJAR: STUDI NATURALISTIK TERHADAP PAMONG BELAJAR DALAM MELAKSANAKAN LAYANAN PROGRAM PENDIDIKAN NON FORMAL
}

\author{
Sri Wahyuni \\ Universitas Mulawarman \\ Email: sri.wahyuni2623@gmail.com
}

\begin{abstract}
Research purpose for: 1)Describe the role of tutors in implementing nonformal education programs, 2)Describe the tutors education qualifications, 3) Identify the tutors obstacles in carrying out their duties and functions. This is a qualitative naturalistic research. The main data sources are tutors and leader of the Center for Early Childhood Education Development and Community Education in East Kalimantan Province. Data collected from the results of field observations, interviews, and documentation studies. Research analysis using an interactive model approach, the stages are data reduction, data display, and verification. The research results: 1) The role of tutors in providing nonformal education service can be seen from their exsistence in carrying out their duties and functions, namely as educators, program reviewers, and model developers. The tutors education qualifications are in accordance with the minimum standard of academic qualifications, namely undergraduate and postgraduate. 3) The obstacles for tutors are: a) Inadequate facilities and infrastructure to carry out the duties and functions of the institution, b) The head of the center has not provided maximum direction regarding the duties and functions of the tutors, c) Proposing a credit score for tutors is difficult, d)Lack of equal opportunities for tutors to be involved in various activities.
\end{abstract}

Keywords: role, tutor, nonformal education program

\section{PENDAHULUAN}

Upaya untuk memenuhi kebutuhan pendidikan dibidang Pendidikan Non Formal (PNF) dibutuhkan layanan program Pendidikan Nonformal yang memiliki kualitas dan mutu yang baik di Kalimantan Timur. Tenaga pendidik yang memadai dan berkualitas merupakan salah satu faktor pendukung. Hanya pendidik yang handal yang mampu menemukan dan paham akan kebutuhan belajar bidang nonformal di wilayahnya sehingga dapat merumuskan metode dan teknik pembelajaran yang tepat sesuai dengan kondisi dan potensi sumber lingkungan warga belajar. Sehingga memotivasi warga belajar untuk mampu 
menggunakan segala potensi lingkungan yang ada sebagai upaya peningkatan kualitas hidup.

Salah satu Pendidik PNF itu adalah Pamong Belajar. Pamong Belajar merupakan tenaga pendidik yang memiliki peran strategis dalam pelaksanaan layanan program-program PNF. Pamong Belajar merupakan Pegawai Negri sipil yang memang spesifik menangani Pendidikan Nonformal. Pamong Belajar berkedudukan sebagai pelaksana teknis fungsional pengembangan model, pengajaran dan pengkajian pada Sanggar Kegiatan Belajar (SKB) dan Unit Pelaksana Teknis Pengembangan Kegiatan Belajar (UPT PKB)/Unit Pelaksana Teknis Daerah PKB (UPTD PKB) atau yang sekarang beralih fungsi menjadi Balai Pengembangan Pendidikan Anak Usia Dini dan Pendidikan Masyarakat yang disingkat BP PAUD dan Dikmas, hal ini tertuang jelas dalam Peraturan Menteri Pendidikan dan Kebudayaan RI nomor 39 tahun 2013. Pamong belajar menurut Norsanie Darlan (2012) memiliki serangkaian tugas dan juga fungsi dalam melaksanakan suatu pembelajaran, membina dan membimbing, serta melakukan penilaian hingga pemantauan guna perbaikan mutu.

Memperhatikan Peraturan Pemerintah oleh Menpan RB nomor 15 Tahun 2010 mengenai Jabatan Fungsional Pamong Belajar (PB) dan Angka Kredit PB. Pada pasal 1 menyatakan bahwa Jabatan Fungsional Pamong Belajar adalah jabatan yang mempunyai ruang lingkup, tugas, tanggung jawab dan wewenang untuk melakukan kegiatan belajar mengajar, pengkajian program, dan pengembangan model Pendidikan Nonformal dan Informal (PNFI) pada Unit Pelaksana Teknis (UPT)/Unit Pelaksana Teknis Daerah (UPTD) dan satuan PNFI sesuai dengan peraturan perundang-undangan yang diduduki oleh Pegawai Negeri Sipil. Selanjutnya pada pasal 2 menyatakan bahwa Pamong Belajar adalah pendidik dengan tugas utama melakukan kegiatan belajar mengajar, pengkajian program, dan pengembangan model Pendidikan Nonformal dan Informal (PNFI) pada Unit Pelaksana Teknis (UPT)/Unit Pelaksana Teknis Daerah (UPTD) dan satuan PNFI (Peraturan Pemerintah No.15 tahun 2010).

Dengan posisi seperti itu, pamong belajar diberikan serangkaian tugas dan tanggung jawab, serta kewenangan dan hak penuh dari pejabat agar dapat melaksanakan kegiatan pembelajaran, mengembangkan model, membuat percontohan program, hingga pengkajian program pendidikan luar sekolah. Dari wacana tersebut terlihat jelas hilangnya tugas dan fungsi pengendalian mutu dan evaluasi dampak yang semula ditanggung oleh pamong belajar namun beralih kepada penilik. Disinilah tantangan pamong belajar dalam menunjukkan kualitas pelayanan program pendidikan luar sekolah, karena mereka tidak lagi bertugas sebagai supervisor tetapi sebagai pihak penyelenggara pendidikan luar sekolah yang di evaluasi dan dimonitoring. Wacana lain yang muncul berkaitan dengan merubah jabatan fungsional pamong belajar menjadi guru PNF. Kemudian, mengutip pada salah satu artikel yang ditulis oleh Fauzi (2016) yang mengatakan 
bahwa wacana tersebut mulai muncul ditahun 2015, dimana ada rencana peralihan dari fungsi suatu Sanggar Kegiatan Belajar/SKB menjadi suatu satuan PNF. Sebuah wacana mengenai peralihan fungsi tersebut ada yang setuju dan tidak, karena terdapat dampak/pengaruh yang positif serta dampak negatif terlebih apabila pamong belajar dirubah menjadi guru pendidikan nonformal.

Salah satu alasan merubah jabatan fungsional pamong belajar menjadi guru PNF supaya pamong belajar dapat mengikuti sertifikasi profesi layaknya sorang guru yaitu berkaitan dengan perolehan tunjangan. Faktor pendorong dari adanya perubahan pamong belajar berubah menjdai guru PNF adalah setifikasi, namun syarat untuk itu mereka harus memiliki kualifikasi pendidikan minimal sarjana pendidikan. Sebagian besar masih banyak pamong belajar yang berlatar pendidikan bukan dari sarjana pendidikan, hal itu akan berdampak negatif pada profesi pamong belajar (Fauzi, 2016).

Adanya wacana untuk merubah pamong belajar SKB menjadi guru PNF dapat berdampak negatif pada jabatan fungsionalnya. Hal serupa juga akan dilakukan perubahan pada pamong belajar yang ada di BP PAUD dan Dikmas yang diisukan akan berubah nama menjadi widyaprada.

Sasaran pendidikan Non formal mencakup segala lapisan masyarakat yang tidak terbatas usia, jenis kelamin, status sosial ekonomi dan tingkat pendidikannya sebelumnya. Program belajar dalam pendidikan Non Formal tidak dibatasi oleh jenjang, bersifat praktis, jangka pendek, program belajarnya berorientasi pada kebutuhan masyarakat, fleksibel, dan ijazah bukan tujuan utama (Waspodo M, 2006). Untuk memberikan layanan PNF diperlukan dukungan yang handal salah satunya yaitu Pamong Belajar. Dalam beberapa kajian yang telah dilakukan bahwa peran pamong belajar memiliki kontribusi yang sangat berpengaruh pada pengembangan program-program pendidikan Luar Sekolah (Lutfi, M,2013). Dalam sistem pendidikan nasional terdapat tiga jalur pendidikan yaitu pendidikan formal, pendidikan nonformal dan pendidikan informal. Semua jalur pendidikan tersebut berfungsi saling menyempurnakan dan melengkapi (Sudjana, 2001).

Pamong belajar merupakan simbol keberagaman, tugas mereka melayani seluruh lapisan masyarakat dibidang pendidikan yang beragam tanpa batasan usia, status sosial, gender, maupun latar belakang pendidikan masyarakat tersebut. Semua wacana perubahan yang muncul seputar pamong belajar diharapkan tidak akan mengurangi mutu pelayanan mereka dalam programprogram pendidikan luar sekolah, bahkan disinilah tantangan pamong belajar dalam menunjukkan eksistensinya dan peranan dalam meningkatkan mutu layanan program pendidikan luar sekolah.

Berdasarkan dari seputar isu-isu wacana dan permasalahan tersebut, maka penulis tertarik untuk melakukan kajian penelitan tentang Peran Pamong Belajar khususnya dalam melaksanakan Layanan Program Pendidikan Nonformal di 
Samarinda. Adapun tujuan penelitian yaitu: 1) Mendeskripsikan peran pamong belajar dalam melaksanakan layanan program pendidikan Nonformal, 2) Mendeskripsikan latar belakang pendidikan pamong belajar, 3) Mengidentifikasi kendala yang dihadapi pamong belajar dalam menjalankan tugas pokok dan fungsinya.

\section{METODE PENELITIAN}

Penelitian ini dilakukan dengan pendekatan secara metodologis dengan menggunakan pendekatan penelitian naturalistik kualitatif. Studi dalam penelitian ini mengambil subjek Pamong belajar dan Kepala BP PAUD dan Dikmas Provinsi Kaltim, untuk melihat peran pamong belajar dalam melaksanakan layanan pendidikan nonformal terkait dengan pelaksanaan tugas pokok dan fungsinya, latar belakang pendidikan pamong belajar BP PAUD dan Dikmas dalam menjalankan tugas pokok dan fungsinya, serta kendala yang dihadapi pamong belajar BP PAUD dan Dikmas dalam menjalankan tugas pokok dan fungsinya terkait dengan program nonformal.

Subjek penelitian yang dijadikan responden utama adalah pamong belajar BP PAUD dan Dikmas Provinsi Kaltim. Selain itu untuk memperluas dan mendukung data/informasi yang diperlukan peneliti juga menggali informasi dari Kepala BP PAUD dan Dikmas Provinsi Kaltim.

Teknik pengumpulan data pada penelitian ini mencakup kegiatan observasi/ pengamatan lapangan, melakukan wawancara, serta mengkaji dokumen pendukung yang berkaitan dengan keperluan data penelitian atau studi dokumentasi. Observasi merupakan kegiatan pengamatan dan pencatatan pada gejala yang tampak pada objek suatu penelitian (S. Margono, 2003). Hal yang perlu diamati adalah aktivitas harian pamong belajar dalam melaksanakan layanan program nonformal. teknik yang utama yang digunakan dalam mengumpulkan data yaitu dengan wawancara, dimana wawancara merupakan suatu alat yang digunakan untuk mengumpulkan informasi dengan mengajukan beberapa pertanyaan lisan kemudian diberikan jawaban dengan cara yang sama. Sumber data yang dijadikan subjek wawancara adalah pamong belajar dan kepala dinas. Studi dokumentasi dalam S. Margono (2003) dilakukan dengan cara mengumpulkan data-data yang ada pada peninggalan tertulis suatu objek penelitian, misalnya arsip, buku tentang suatu pendapat, sebuah teori, dalil/hukum, serta hal-hal yang berkaitan dengan permsalahan dalam penelitian. Data pendukung yang perlu ada adalah dengan mempelajari dokumen-dokumen lembaga yang berkaitan dengan kegiatan pamong belajar di BP PAUD dan Dikmas Samarinda.

Analisis data penelitian menggunakan pendekatan model interaktif Miles dan Huberman (2016) dengan tahap reduksi data, sajian data, dan verifikasi. Proses analisis melalui beberapa tahapan mulai dari mengumpulkan semua data 
lapangan yang didapat dari hasil kegiatan pengamatan langsung, intervui/wawancara, hingga mengkaji dan menemukan dokumen yang berkaitan dengan masalah penelitian. Tahap selanjutnya yaitu membandingkan data yang diperoleh dari hasil wawancara dari masing-masing sumber data dengan data yang diperoleh dengan mempelajari dokumen lembaga yang mendukung serta pengamatan yang telah dilakukan. Data yang telah ada disajikan dalam bentuk deskripsi narasi, tabel, maupun diagram. Penarikan kesimpulan adalah langkah terakhir dalam analisis tersebut yang menggambarkan hal-hal yang menjadi jawaban atas beberapa rumusan masalah yang dikaji.

\section{HASIL DAN PEMBAHASAN}

Keadaan Pamong Belajar di Balai Pengembangan PAUD dan Dikmas Kalimantan Timur ditinjau dari Latar Belakang Pendidikannya.

Berdasarkan data SIM PTK PNF BP Paud dan Dikmas Prov. Kaltim jumlah pamong belajar sebanyak 22 orang yang bestatus PNS/ASN yang terdiri dari 8 orang Pamong Madya dan 14 orang Pamong Muda, data tersebut dapat disajikan pada gambar diagram berikut ini:

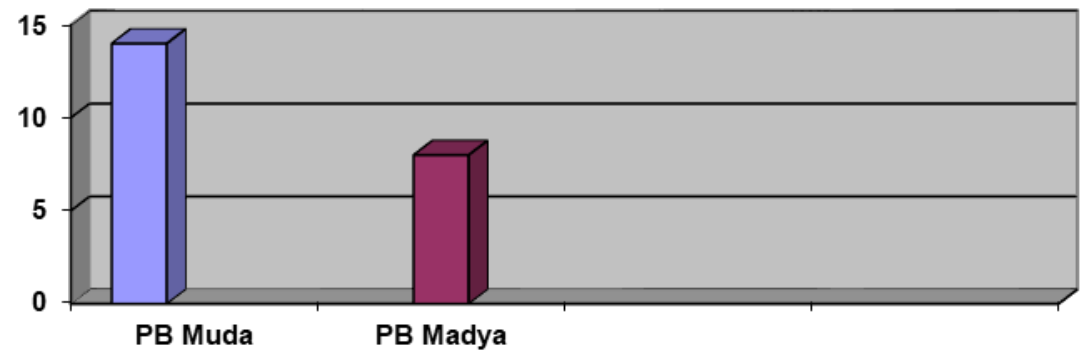

Gambar 1. Data Pegawai Negeri Sipil Jabatan Fungsional Pamong Belajar Berdasarkan Jenjang Jabatannya (Sumber : BP PAUD dan Dikmas Kaltim)

Dari hasil studi dokumentasi yang dilakukan peneliti diperoleh data pendidikan pegawai negeri sipil jabatan fungsional pamong belajar dengan latar belakang pendidikan S1 sebanyak 10 orang atau $45 \%$ dan S2 sebanyak 12 orang atau $55 \%$ dengan masing-masing disiplin keilmuan yang berbeda-beda. Berikut ini dapat disajikan pada gambar diagram di bawah ini: 


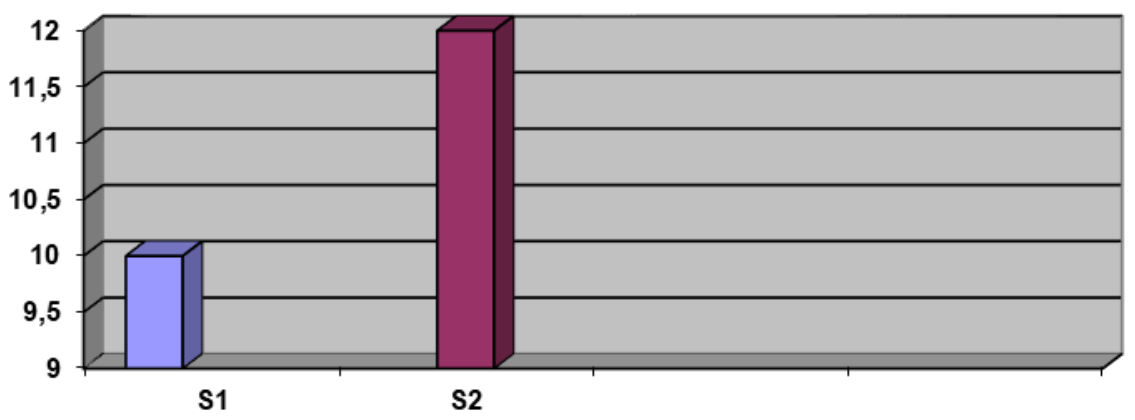

Gambar 2. Data Pegawai Negeri Sipil Jabatan Fungsional Pamong Belajar Berdasarkan Jenjang Pendidikannya(Sumber : BP PAUD dan Dikmas Kaltim)

Berdasarkan pada gambar diagram di atas terlihat bahwa sebagian besar latar belakang pendidikan pamong belajar BP Paud dan Dikmas sudah memenuhi standar minimum kualifikasi akademik, yaitu dengan kualifikasi/jenjang pendidikan sarjana. Keadaan tersebut sudah sesuai dengan ketentuan bahwa standar mutu pendidikan pamong belajar adalah paling rendah Strata 1 sampai Strata 2 (Bartin, 2016).

Data pamong belajar juga dapat dilihat berdasarkan disiplin keilmuannya, seperti gambar di bawah ini:
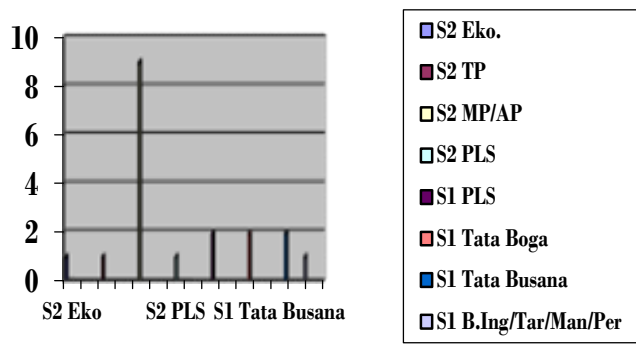

Gambar 3.Data Pegawai Negeri Sipil Jabatan Fungsional Pamong Belajar Berdasarkan Latar Belakang Pedidikannya(Sumber : BP PAUD dan Dikmas Kaltim)

Gambar diagram batang di atas menggambarkan bahwa pamong belajar BP Paud dan Dikmas sejumlah 22 orang memiliki jenjang pendidikan dan latar belakang pendidikan yang beragam. Berdasarkan data yang diperoleh menunjukan bahwa jumlah pamong belajar dengan latar belakang S1 PLS 
sebanyak 2 orang yang terdiri dari PB Madya dan PB Muda, S1 Tata Boga sebanyak 2 orang PB muda, S1 Tata Busana sebanyak 2 orang PB muda, S1 Bahasa Inggris, Tarbiah, Manajemen, dan Pertanian masing-masing sebanyak 1 orang yang terdiri dari PB Madya dan PB Muda, S2 PLS sebanyak 1 orang PB Madya, S2 Manajemen Pendidikan/Administrasi Pendidikan sebanyak 9 orang yang terdiri dari 3 orang PB Madya dan 6 orang PB Muda, S2 Ekonomi dan S2 Teknologi Pendidikan masing-masing sebanyak 1 orang PB Madya.

\section{Peran Pamong Belajar BP PAUD dan Dikmas dalam melaksanakan Layanan Program Pendidikan Masyarakat}

Pamong belajar dalam menjalankan peranannya harus sejalan dengan tugas dan fungsi lembaga, sebagaimana tugas Balai Pengembangan Pendidikan Anak Usia Dini dan Pendidikan Masyarakat yaitu melaksanakan pengembangan program dan pengembangan mutu Pendidikan Anak Usia Dini dan Pendidikan Masyarakat. Hal ini sejalan dengan makna pamong yang dikemukakan oleh Moeliono (1989) yaitu pamong berperan sebagai pengasuh atau pembimbing dan pendidik.

Peran merupakan aspek dinamis dari status seseorang, status individuindividu sejak lahir yaitu status tanpa memandang kemampuan atau keahlian atau status yang dimiliki seseorang karena dia memiliki kualitas tertentu (Maryati dan Suryawati, 2009). Dalam kamus besar bahasa Indonesia peran merupakan sebagai perangkat tingkah laku yang diharapkan dimiliki oleh orang yang berkedudukan di masyarakat (Depdiknas, 2008). Untuk mewujudkan tujuan dari lembaga maka, pamong belajarlah yang berperan penting sebagai ujung tombak pelaksana segala rangkaian tugas pokok dan wewenang untuk mewujudkan tercapainya visi misi Balai Pengembangan Paud dan Dikmas Provinsi Kalimantan Timur.

Mengacu pada Peraturan pemerintah oleh Menpan RB nomor 15 tahun 2010 mengenai jabatan fungsional dan angka kredit pamong belajar dapat terlihat dengan jelas bahwa eksistensi pamong belajar dapat ditunjukkan dalam pelaksanaan tugas pokok dan fungsi kelembagaannya. Hal tersebut merupakan suatu gambaran dari peran pamong belajar dalam memberikan dan meningkatkan mutu layanan program Paud dan Dikmas di Kalimantan Timur.

Peran pamong belajar berkaitan juga dengan kualitas atau mutu layanan yang diberikan dalam melaksanakan program nonformal maupun tugas kelembagaannya. Sebagaimana halnya teori yang dikemukakan oleh (Edwar sallis, 2011) bahwa mutu bukan sebagai suatu atribut produk atau layanan, tetapi sesuatu yang dianggap berasal dari produk atau layanan tersebut. Dapat dirincikan peran pamong belajar BP Paud dan Dikmas Kaltim adalah sebagai berikut: 


\section{Sebagai Pendidik dengan menjalankan KBM}

Melaksanakan fungsi/peran sebagai pendidik dengan tugas belajar mengajar merupakan salah satu tugas pokok pamong belajar yang ada di Balai Pengembangan pendidikan anak usia dini dan pendidikan masyarakat, meskipun tugas pokoknya lebih banyak dan terfokus pada tugas pengkajian program dan pengembangan model tetap saja KBM ini merupakan bagian dari serangkaian tugas pokok pamong belajar yang sudah diatur lembaga dan pemerintah dan harus dilaksanakan meskipun mereka tidak beorientasi penuh melaksanakan KBM sebagaimana tugas pokok pamong di SKB karena kebanyakan mereka berstatus sebagai pengelola program Paud dan Dikmas. Peran pamong sebagai pendidik merupakan bagian terpenting atau unsur pokok dalam pelaksanaan KBM pendidikan nonformal, hal ini sejalan dengan teori Sudjana (2008) bahwa unsur yang harus ada dalam program pendidikan nonformal sesuai dengan 10 Patokan Pendidikan Masyarakat yaitu terdapat kelompok belajar, tujuan belajar, warga belajar, sumber belajar, sarana belajar, pamong belajar, ragi belajar, panti belajar, dana belajar, dan hasil belajar.

Peran pamong belajar BP Paud dan Dikmas dalam menjalankan fungsinya sebagai pendidik dengan tugas KBM dapat dirincikan sebagai berikut:

1) Melakukan Perencanaan Pembelajaran/Pelatihan/Pembimbingan, kegiatan yang dilakukan yaitu: (a) Mengidentifikasi penyelenggaraan program Pendidikan anak usia dini dan pendidikan masyarakat, yaitu kegiatan mencari, menemukan, mengumpulkan, data sasaran program, seperti informasi pendidik, warga belajar, sumber dan relasi pendukung, hingga fasilitas pendukung program (b) Melakukan analisis hasil kegiatan identifikasi pelaksanaan program, yaitu pamong belajar mengolah, nyajikan, dan menganalisis data-data yang telah dikumpulkan yang terkait dengan program yang akan dilaksanakan. (c) Melaksanakan pemantapan persiapan kegiatan pembelajaran, pelatihan dan pembimbingan, yaitu dengan cara memberikan motivasi dan bimbingan pada semua yang terlibat dalam terselenggaranya program (d) Merumuskan rencana dalam pembelajaran baik yang digunakan dalam kegiatan pelatihan maupun pembimbingan dalam satuan pendidikan masyarakat/nonformal dengan cara: membuat rancangan program, silabus, dan Rencana Pelaksanaan Pembelajaran (RPP).

2) Pelaksanaan Proses Pembelajaran/Pelatihan/Pembimbingan, yang merupakan suatu proses interaksi yang dilakukan pamong belajar sebagai pendidik dengan warga belajar agar tercapainya tujuan dari kegiatan tersebut sesuai dengan rancangan pembelajaran yang telah disusun.

3) Penilaian Hasil Pembelajaran/Pelatihan/Pembimbingan, Kegiatan dilaksanakan dengan cara: (a) Membuat alat penilaian atau pengukuran dari hasil proses belajar pada kegiatan tersebut dengan tes maupun non tes. (b) Menilai dan mengevaluasi hasil kegiatan tersebut yaitu data dari hasil kegiatan 
tersebut dikumpulkan dan diolah kemudian dilakukan pengukuran dan penilaian dengan alat/instrument penilaian pada hasil belajar warga belajar. (c) Melakukan kegiatan analisis hasil evaluasi, yaitu hasil evaluasi dari kegiatan tersebut diolah, ditelaah, disajikan dan disimpulkan. (d) Menyelenggarakan forum diskusi terfokus/FGD terhadap hasil evaluasi kegiatan tersebut. Hal yang dibahas yaitu tentang perbaikan mutu penyelenggaraan kegiatan yang telah terselenggara serta untuk mengulas fakor pendukung dan penghambatnya. (e) Melakukan kegiatan perbaikan serta pengayaan pembelajaran dari hasil diskusi terfokus, yaitu dengan cara menambah kegiatan pembelajaran hingga tujuan pembelajaran tercapai.

\section{Sebagai Pengkaji Program Paud dan Dikmas}

Peran pamong belajar selanjutnya yaitu sebagai pengkaji program pada bidang Pendidikan anak usia dini dan pendidikan masyarakat. Kegiatan ini dilakukan dengan mengumpulkan dan menelaah data yang berhubungan dengan penyelenggaraan program, dengan terencana dan secara sistematis dengan menggunakan alat dan cara ilmiah khusus sebagai pengatur derajat ketercapaian dan berhasilnya suatu tujuan dari program tersebut.

Program yang dikaji oleh pamong belajar terkait dengan program pendidikan nonformal. Sebagaimana halnya program pendidikan nonformal yang dikemukakan Hiryanto(2010)bahwa program pendidikan nonformal yaitu program pendidikan yang ada dalam Undang-Undang nomor 20 tahun 2003, tentang Sistem Pendidikan Nasional, khususnya mengenai pendidikan nonformal meliputi pendidikan kecakapan hidup, pendidikan anak usia dini, pendidikan kepemudaan, pendidikan pemberdayaan perempuan, pendidikan keaksaraan, pendidikan keterampilan dan pelatihan kerja, pendidikan kesetaraan, serta pendidikan lain yang ditujukan untuk mengembangkan kemampuan peserta didik.

Peran pamong belajar dalam hal ini mengacu pada program yang dibagi pada 4 kelompok kerja atau bidang, yang terdiri dari kelompok kajian PAUD, kelompok bidang pendidikan keluarga, kelompok bidang keaksaraan dan kesetaraan, serta kelompok bidang pelatihan dan kursus. Pada setiap kelompok kerja atau bidang terdapat ditunjuk seorang ketua yang memiliki keahliannya yang relevan bidang kajiannya kerjanya. Hal ini bertujuan agar pamong belajar lebih terfokus bidang kajian kerjanya. Anggota kelompok kerja terdiri dari 3-4 orang pamong belajar yang telah berpengalaman dalam mengembangkan model dan menyelenggarakan kegiatan percontohan dalam pembelajaran. Kepala balai bertugas membina dan bertanggung jawab atas pengelompokkan kerja tersebut. Kegiatan pada pengkajian program tersebut terdiri atas tahap persiapan dan pelaksanaan pengkajian program bidang kerja. 


\section{Sebagai Pengembang Model Program Paud dan Dikmas}

Peran pamong belajar BP Paud dan Dikmas berikutnya yaitu sebagai pengembang model Paud dan Pendidikan Masyarakat. Model merupakan produk hasil pengembangan pamong belajar. Kegiatan pengembang model merupakan suatu usaha menemukan hal inovatif pada bidang Pendidikan anak usia dini dan Pendidikan Masyarakat yang dikembangkan sesuai pedoman dan metodelogi ilmiah tertentu sehingga menghasilkan formulasi yang dikehendaki. Setiap tahunnya paling sedikit ada empat sampai delapan macam model pengembangan program yang dihasilkan oleh pamong belajar dengan masing-masing bidang kelompok kajiannya.

Secara garis besar kegiatan pengembangan model Paud dan Dikmas meliputi tahapan perencanaan dan pelaksanaan, berikut ini dapat dirincikan sebagai berikut : 1) Penyusunan rancangan/desain yaitu: proses kegiatan yang dilakukan secara logis dan sistematis dalam menyusun suatu alur atau kerangka berpikir, media atau bahan, serta alat pendukung kegiatan sesuai pedoman dalam mengembangkan model program, 2) Pelaksanaan, yaitu proses/tahapan penerapan dari suatu desain yang dikembangkan pada model program dalam bidang tersebut.

Sebelum melaksanakan pengembangan model/uji coba model dilakukan terlebih dahulu workshop draf model dalam bentuk FGD (diskusi terfokus) untuk melakukan revisi draf model sebelum dilaksanakan uji coba model setelah itu penerapan desain model program pengembangan.

Selain menjalankan tugas pokoknya, pamong belajar juga dituntut untuk dapat melakukan pengembangan profesi seperti : membuat karya tulis ilmiah, pengembangan sarana pendidikan, pengembangan karya teknologi tepat guna, seni dan olahraga yang bermanfaat, serta menyusun rambu/kisi-kisi soal sesuai pedoman dan lainnya.

Ada beberapa kompetensi yang dapat menunjang pelaksanaan tugas seorang pamong belajar serta dapat meningkatkan angka kreditnya, yang diwujudkan dalam :

a) Kegiatan pengabdian pada masyarakat, seperti : ada beberapa pamong yang menjalankan tugas pengabdian masyarakatnya yaitu sebagai asesor BAN Paud dan PNF dan pamong belajar yang diangkat menjadi tim penilai angka kredit pamong belajar.

b) Keikutsertaan dalam seminar/workshop/lokakarya pendidikan, seperti: Diklat pelayanan publik yang berlangsung pada bulan juli 2017 di Depok.

c) Prestasi dibidang pendidikan 
d) Memperoleh penghargaan tanda jasa/memperoleh ijazah gelar, seperti yang diwujudkan dalam bentuk penghargaan gelar satya lencana 10 tahun bagi pamong belajar.

e) Berperan aktif dalam penerbitan jurnal/majalah dibidang Paud dan Dikmas.

Pamong belajar menjalankan tupoksi kerjanya sesuai dengan jenjang jabatannya, namun bukan tidak mungkin pamong belajar dapat diberi tugas yang lebih tinggi atau di bawah dari jabatannya dengan catatan mereka mempunyai kemampuan dan keahlian dalam melaksanakan tugas yang diberikan oleh pimpinan.

\section{Kendala yang Dihadapi Pamong Belajar dalam Menjalankan Tugas Pokok dan Fungsinya}

Berdasarkan hasil temuan lapangan teridentifikasi beberapa kendala atau faktor penghambat pamong belajar dalam melaksanakan tugas dan tanggung jawabnya. Berikut ini beberapa kendala yang dihadapi pamong belajar, diantaranya yaitu:

a. Kurangnya sarana prasarana penunjang seperti komputer dan printer, selama ini pamong menggunakan fasilitas milik pribadi dan ditunjang dengan fasilitas seadanya yang tersedia di kantor.

b. Kurangnya pembinaaan dari atasan langsung tentang tugas dan fungsi pamong belajar,

c. Tidak mudah berkonsultasi dalam pengusulan angka kredit pamong belajar karena semua alih fungsi langsung ke pusat.

d. Kurang adanya pemerataan kesempatan untuk pamong belajar dilibatkan dalam kepanitiaan maupun menjadi narasumber teknis dalam beberapa kegiatan seperti : seminar, lokakarya, workshop, diklat, dan bimtek yang diselenggarakan oleh Balai Pengembangan Paud dan Dikmas maupun dari luar.

Hasil identifikasi pada kajian ini sejalan dengan kajian penelitian yang telah ada sebelumnya oleh Ade (2014) yaitu kendala pamong dalam penggunaan sarana prasarana pendukung, kelompok kerja, cara kerja serta unsur lingkungan pekerjaan. Pada penelitian sebelumnya juga ditemukan kendala yaitu lemahnya unsur supervisi dari pusat serta penghargaan dan perlindungan profesi yang lemah dari pemerintah daerah karena kurang faham akan fungsi dan tugas pamong belajar sehingga berdampak juga pada proses kenaikan pangkat Bartin (2016)dan Lutfi (2013). Oleh karena itu, hal utama yang sangat diperlukan pamong belajar adalah kesempatan untuk berinovasi dan kreasi dalam mengembangkan kompetensinya, reward, serta adanya sarana prasarana kerja yang mendukung. 


\section{SIMPULAN}

Hasil penelitian menunjukkan bahwa: 1) Peran Pamong Belajar dalam melaksanakan Layanan Program PNF dapat dilihat dari eksistensi pamong belajar dalam melaksanakan tugas pokok dan fungsi kelembagaannya, yaitu dengan menjalankan perannya sebagai pendidik dengan Kegiatan Belajar Mengajar, Pengkaji Program, dan Pengembang Model. 2) Latar Belakang Pendidikan pamong belajar di BP Paud dan Dikmas sudah memenuhi standar minimum kualifikasi akademik, yaitu jenjang pendidikan sarjana, dengan jumlah S1 sebanyak 10 orang atau $45 \%$ dan S2 sebanyak 12 orang atau $55 \%$ dengan masing-masing disiplin keilmuan yang berbeda-beda. 3) Kendala yang dihadapi Pamong Belajar dalam menjalankan tugas pokok dan fungsi kelembagaannya yaitu : a) Kurangnya sarana prasarana pendukung untuk penunjang pelaksanaan tupoksi pamong belajar, b) Kurangnya pembinaaan dari atasan langsung tentang tugas dan fungsi pamong belajar, c) Kesulitan berkonsultasi dalam pengusulan angka kredit pamong belajar karena semua alih fungsi langsung ke pusat, d) Kurang adanya pemerataan kesempatan untuk pamong belajar dilibatkan dalam kepanitiaan maupun menjadi narasumber teknis dalam beberapa kegiatan.

\section{SARAN DAN REKOMENDASI}

Berdasarkan pada hasil dan kesimpulan dari penelitian ini dapat disampaikan saran dan rekomendasi terkait dengan pamong belajar. Untuk dapat terlaksananya program pendidikan nonformal dengan maksimal perlu adanya pembinaan, dukungan, dan kerjasamanya yang baik antara pimpinan dan pamong belajar agar dapat meningkatkan mutu layanan program pendidikan nonformal serta tercapainya visi misi Balai Pengembangan Paud dan Dikmas. Pamong belajar hendaknya diberi lebih banyak kesempatan dan dilibatkan pada berbagai kegiatan pengembangan kompetensi agar dapat meningkatkan kinerja pamong belajar. Perlu adanya apresiasi dan perhatian serta penunjang kesejahteraan dari pemerintah terkait dengan tugas dan fungsi pamong belajar. Penyediaan fasilitas yang lebih memadai untuk penunjang tugas pamong belajar.

\section{DAFTAR PUSTAKA}

Ade, Ramandha. (2014). Pembinaan Tugas Pokok dan Fungsi Pamong Belajar oleh Kepala SKB dalam mengoptimalkan Kinerja Pamong: Studi di SKB Wilayah 2 Kota Padang. Thesis, Universitas Pendidikan Indonesia.Diunduh tanggal 28 Oktober 2021. http://repository.upi.edu/id/eprint/11713.

Bartin, Tasril. (2016). Prosiding Seminar Nasional dengan Tema Kompetensi Pendamping Pembangun Desa di UNP. Urgensi Pengembangan Kompetensi Pamong Belajar Dalam Pelayanan Program Pendidikan Luar Sekolah sebagai Bagian Upaya Pemberdayaan Masyarakat Desa.Hal: 210-224. 
Darlan, H.M.Noersani. (2012). Pamong Belajar dalam menjalankan Tupoksinya pada Pendidikan Luar Sekolah. Diunduh 28 Oktober 2021.http://norsanie.blogspot.com/2012/12/pamong-belajar-dalammenjalankan.html.

Hiryanto. (2010). Pengendalian Mutu Program Pendidikan Nonformal dan Informal. Jogyakarta: Balai Pengembangan Kegiatan Belajar (BPKB).

Lutfi, M. (2013). Aplikasi Hasil Pelatihan Pamong Belajar dalam Pengembangan Program Pendidikan Luar Sekolah: Studi Kasus di Jayagiri Bandung Barat. Thesis, Universitas Pendidikan Indonesia, diunduh tanggal 28 oktober 2021.http://repository.upi.edu/id/eprint/770.

Margono, S. (2003). Metodologi Penelitian Pendidikan. Jakarta:PT Rineka Cipta.

Miles, B, Matthew, dkk. (1992). Analisis Data Kualitatif.Jakarta: Universitas Indonesia (UI-Press).

Moeliono, Anton. (1989).Kamus Besar Bahasa Indonesia. Jakarta: Kementrian Pendidikan Nasional, Pusat Pembinaan dan Pengembangan Bahasa.

Peraturan Menteri Pendidikan dan Kebudayaan RI Nomor 39. (2013). Petunjuk Teknis Jabatan Fungsional Pamong Belajar dan Angka Kreditnya. Jakarta.

PP nomor 15. (2010). Kementrian Negara Pendayagunaan Aparatur Negara dan Reformasi Berokrasi, tentang: Jabatan Fungsional Pamong Belajar Dan Angka Kreditnya. Jakarta.

Pranyono, E, Fauzi. 2016. Dampak Perubahan Pamong Belajar menjadi Guru Pendidikan Nonformal. Diunduh 28 Oktober 2021. http://fauziep.com/dampak-perubahan-pamong-belajar-menjadi-gurupendidikan-nonformal/

Sallis, Edward. (2011). Manajemen Mutu terpadu Pendidikan, terjemahan Ahmad Ali Riyadi dan Fahrurrozi. Jogjakarta: IRCiSoD.

Sudjana, Djudju. (2001). Pendidikan Luar Sekolah: Wawasan, Sejarah Perkembangan, Falsafah \& Teori Pendukung, serta Asas. Bandung : Falah Production.

Sudjana, Djudju. (2008). Evaluasi Pendidikan Luar Sekolah untuk Pendidikan Nonformal dan Pengembangan Sumber Daya Manusia. Bandung: PT Remaja Rosdakarya.

Waspodo, Muktiono. (2006). Jurnal Ilmiah Visi PTK-PNF. Pemetaan Perkembangan Pendidik dan Tenaga Kependidikan Pendidikan Non Formal. Vol.1. pp.27-36. 